Prepared in cooperation with the Texas Water Development Board

\title{
Analysis of Trends in Selected Streamflow Statistics for the Concho River Basin, Texas, 1916-2009
}

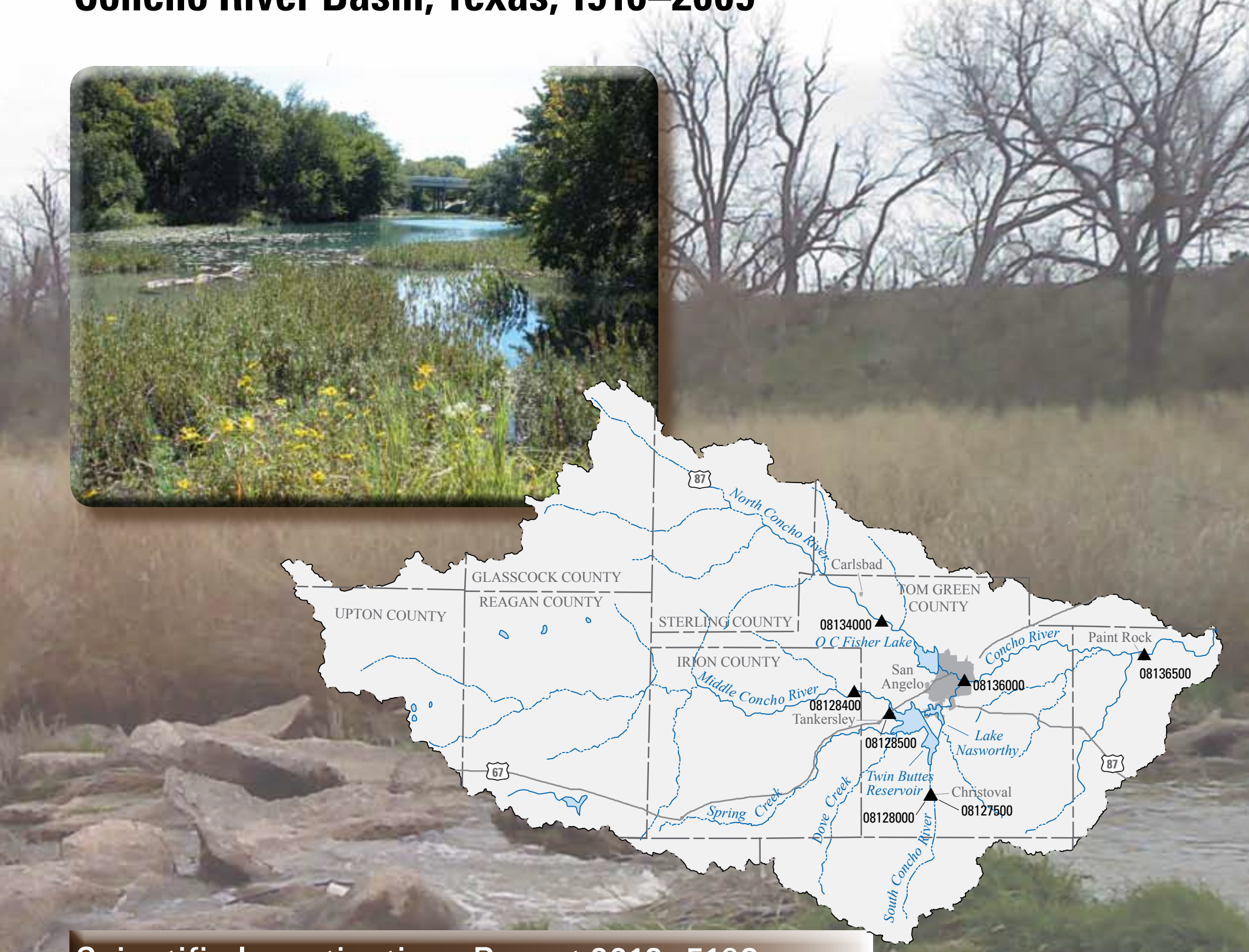

Scientific Investigations Report 2012-5193 
Front cover: South Concho River looking upstream at U.S. Geological Survey streamflow-gaging station 08128000 South Concho River at Christoval, Texas (photograph taken January 5, 2010 by Travis Dowell, U.S. Geological Survey).

Background: Concho River looking downstream from U.S. Geological Survey streamflow-gaging station 08136500 Concho River at Paint Rock, Texas (photograph taken on March 9, 2012, by Henry Jacques, U.S. Geological Survey).

\section{Back cover:}

Top, The dry streambed of Middle Concho River looking downstream from U.S. Geological Survey streamflow-gaging station 08128400 Middle Concho River above Tankersley, Texas (photograph taken November 6, 2009, by Greg Webb, U.S. Geological Survey).

Bottom, North Concho River looking upstream from U.S. Geological Survey streamflow-gaging station 08134000 North Concho River near Carlsbad, Texas (photograph taken November 6, 2009, by Patrick Boyd, U.S. Geological Survey). 


\section{Analysis of Trends in Selected Streamflow Statistics for the Concho River Basin, Texas, 1916-2009}

By Dana L. Barbie, Loren L. Wehmeyer, and Jayne E. May

Prepared in cooperation with the Texas Water Development Board

Scientific Investigations Report 2012-5193 


\title{
U.S. Department of the Interior \\ KEN SALAZAR, Secretary \\ U.S. Geological Survey \\ Marcia K. McNutt, Director
}

\section{U.S. Geological Survey, Reston, Virginia: 2012}

\author{
This and other USGS information products are available at http://store.usgs.gov/ \\ U.S. Geological Survey \\ Box 25286, Denver Federal Center \\ Denver, CO 80225 \\ To learn about the USGS and its information products visit http://www.usgs.gov/ \\ 1-888-ASK-USGS
}

\footnotetext{
Any use of trade, product, or firm names is for descriptive purposes only and does not imply endorsement by the U.S. Government.

Although this report is in the public domain, permission must be secured from the individual copyright owners to reproduce any copyrighted materials contained within this report.
}

Suggested citation:

Barbie, D.L., Wehmeyer, L.L., and May, J.E., 2012, Analysis of trends in selected streamflow statistics for the Concho River Basin, Texas, 1916-2009: U.S. Geological Survey Scientific Investigations Report 2012-5193, 15 p. 


\section{Contents}

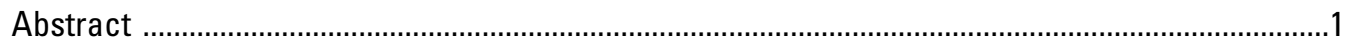

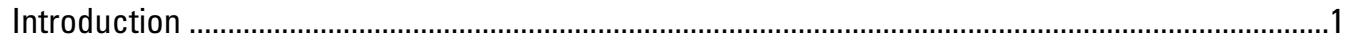

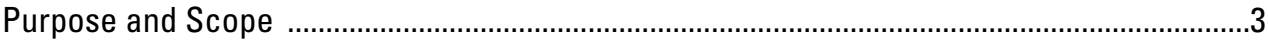

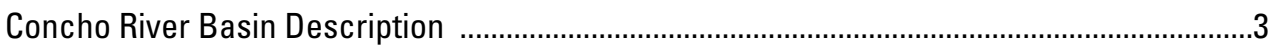

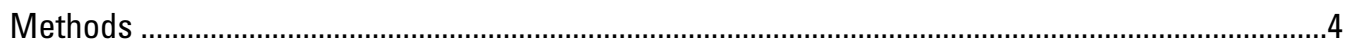

Analysis of Trends in Selected Streamflow Statistics ..................................................................

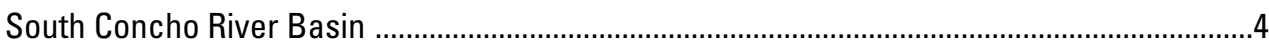

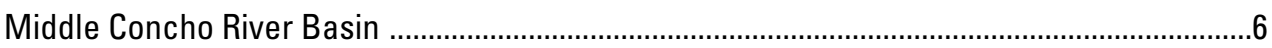

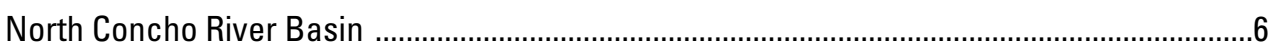

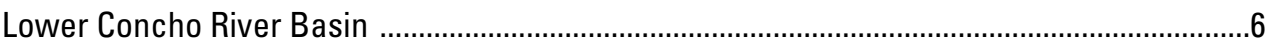

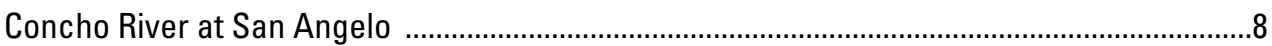

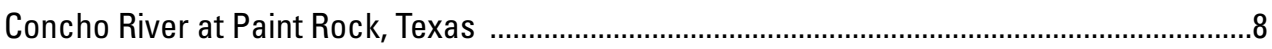

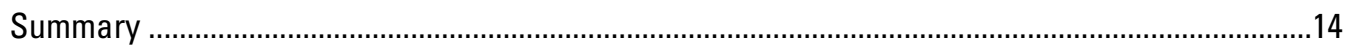

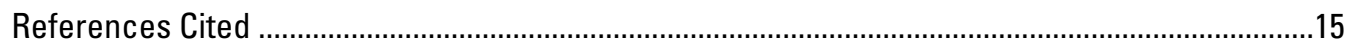

\section{Figures}

1. Map showing selected U.S. Geological Survey surface-water monitoring stations in the Concho River Basin, Texas

2. Graph showing annual mean daily discharge for U.S. Geological Survey surface-water monitoring stations 08128000 South Concho River near Christoval, Texas and 08127500 South Concho Irrigation Canal at Christoval, Tex., along with the estimated combined annual mean daily discharge

3. Graph showing annual mean daily discharge for U.S. Geological Survey streamflow-gaging stations 08128400 Middle Concho River above Tankersley, Texas, and 08128500 Middle Concho River near Tankersley, Tex.

4. Graph showing annual mean daily discharge for U.S. Geological Survey streamflow-gaging station 08134000 North Concho River near Carlsbad, Texas ............9

5. Graph showing annual mean daily discharge for U.S. Geological Survey streamflow-gaging station 08136000 Concho River at San Angelo, Texas

6. Graph showing annual mean daily discharge for U.S. Geological Survey streamflow-gaging station 08136500 Concho River at Paint Rock, Texas

\section{Tables}

1. Selected U.S. Geological Survey surface-water monitoring stations in the Concho River Basin, Texas, 1915-2009

2. Results of Kendall's Tau statistical test for detection of monotonic trends in select streamflow statistics for U.S. Geological Survey streamflow-gaging station 08128000 South Concho River at Christoval, Texas

3. Results of Kendall's Tau statistical test for detection of monotonic trends in select streamflow statistics for $A$, U.S. Geological Survey streamflow-gaging station 08128400 Middle Concho River above Tankersley, Texas, and B, U.S. Geological Survey streamflow-gaging station 08128500 Middle Concho River near Tankersley, Tex. 
4. Results of Kendall's Tau statistical test for detection of monotonic trends in select streamflow statistics for U.S. Geological Survey streamflow-gaging station 08134000 North Concho River near Carlsbad, Texas

5. Results of Kendall's Tau statistical test for detection of monotonic trends in select streamflow statistics for U.S. Geological Survey streamflow-gaging station 08136000 Concho River at San Angelo, Texas

6. Results of Kendall's Tau statistical test for detection of monotonic trends in select streamflow statistics for U.S. Geological Survey streamflow-gaging station 08136500 Concho River at Paint Rock, Texas

\section{Conversion Factors}

\section{Inch/Pound to SI}

\begin{tabular}{|c|c|c|}
\hline Multiply & By & To obtain \\
\hline \multicolumn{3}{|c|}{ Length } \\
\hline foot (ft) & 0.3048 & meter $(\mathrm{m})$ \\
\hline mile (mi) & 1.609 & kilometer $(\mathrm{km})$ \\
\hline \multicolumn{3}{|c|}{ Area } \\
\hline acre & 4,047 & square meter $\left(\mathrm{m}^{2}\right)$ \\
\hline acre & 0.4047 & hectare (ha) \\
\hline acre & 0.4047 & square hectometer $\left(\mathrm{hm}^{2}\right)$ \\
\hline acre & 0.004047 & square kilometer $\left(\mathrm{km}^{2}\right)$ \\
\hline square mile $\left(\mathrm{mi}^{2}\right)$ & 259.0 & hectare (ha) \\
\hline square mile $\left(\mathrm{mi}^{2}\right)$ & 2.590 & square kilometer $\left(\mathrm{km}^{2}\right)$ \\
\hline \multicolumn{3}{|c|}{ Flow rate } \\
\hline cubic foot per second $\left(\mathrm{ft}^{3} / \mathrm{s}\right)$ & 0.02832 & cubic meter per second $\left(\mathrm{m}^{3} / \mathrm{s}\right)$ \\
\hline
\end{tabular}

Horizontal coordinate information is referenced to the North American Datum of 1983 (NAD 83). 


\title{
Analysis of Trends in Selected Streamflow Statistics for the Concho River Basin, Texas, 1916-2009
}

\author{
By Dana L. Barbie, Loren L. Wehmeyer, and Jayne E. May
}

\section{Abstract}

The Concho River Basin is part of the upper Colorado River Basin in west-central Texas. Monotonic trends in streamflow statistics during various time intervals from 1916-2009 were analyzed to determine whether substantial changes in selected streamflow statistics have occurred within the Concho River Basin. Two types of U.S. Geological Survey streamflow data comprise the foundational data for this report: (1) daily mean discharge (daily discharge) and (2) annual instantaneous peak discharge. Trend directions are reported for the following streamflow statistics: (1) annual mean daily discharge, (2) annual 1-day minimum discharge, (3) annual 7-day minimum discharge, (4) annual maximum daily discharge, and (5) annual instantaneous peak discharge.

The South Concho, Middle Concho, and North Concho Rivers drain the upper part of the Concho River Basin. The North and South Concho Rivers converge in San Angelo, Tex., to form the Concho River. The Concho River flows east from San Angelo to its confluence with the Colorado River east of Paint Rock, Tex. The trend analyses principally focused on application of the nonparametric Kendall's Tau statistical test to detect monotonic trends (dependency) in streamflow with time; in other words, Kendall's Tau is a test of temporal independence of streamflow with time. A positive Tau indicates an upward monotonic streamflow trend; conversely, a negative Tau indicates a downward monotonic streamflow trend. Hence, the trend analysis reported here is limited to direction and not magnitude of streamflow change.

Six U.S. Geological Survey streamflow-gaging stations were selected for analysis. Streamflow-gaging station 08128000 South Concho River at Christoval has downward trends for annual maximum daily discharge and annual instantaneous peak discharge for the combined period 1931-95, 2002-9. Streamflow-gaging station 08128400 Middle Concho River above Tankersley has downward trends for annual maximum daily discharge and annual instantaneous peak discharge for the combined period 1962-95, 2002-9. Streamflow-gaging station 08128500 Middle Concho River near Tankersley has no significant trends in the streamflow statistics considered for the period 1931-60. Streamflowgaging station 08134000 North Concho River near Carlsbad has downward trends for annual mean daily discharge, annual 7-day minimum daily discharge, annual maximum daily discharge, and annual instantaneous peak discharge for the period 1925-2009. Streamflow-gaging stations 08136000 Concho River at San Angelo and 08136500 Concho River at Paint Rock have downward trends for 1916-2009 for all streamflow statistics calculated, but streamflow-gaging station 08136000 Concho River at San Angelo has an upward trend for annual maximum daily discharge during 1964-2009. The downward trends detected during 1916-2009 for the Concho River at San Angelo are not unexpected because of three reservoirs impounding and profoundly regulating streamflow.

\section{Introduction}

The Concho River Basin is part of the upper Colorado River Basin in west-central Texas, principally in Tom Green, Irion, Reagan, and Sterling Counties and to a lesser degree in Coke, Concho, Crockett, Glasscock, Howard, Midland, Runnels, Schleicher, and Upton Counties (fig. 1). The population of the Concho River Basin is approximately 120,000, and most of the residents (approximately 93,200 in 2010) live in San Angelo (fig. 1) (U.S. Census Bureau, 2012). The major water demands (withdrawals) in the basin are for public (municipal) supply, ranching, irrigated agriculture, and oil and gas production. Public water supply in San Angelo historically has been provided by streamflow stored in O.H. Ivie and Twin Buttes Reservoirs, Lakes Nasworthy and E.V. Spence, and O.C. Fisher Lake (fig. 1). Although streamflow supplies some water for irrigation, most agriculture land is irrigated with groundwater. Tom Green County has the largest area under irrigation (about 40,000 acres in 2007) (Region F Water Planning Group, 2009). Groundwater is the predominant water source for the rural population, ranching, and oil and gas production in the study area. Because the Concho River Basin provides water stored for public water supply for most residents in the study area, trends in streamflow in the Concho River Basin are of interest to water managers in this part of west Texas. Accordingly, the U.S. Geological Survey (USGS), in cooperation with the Texas Water Development Board, 


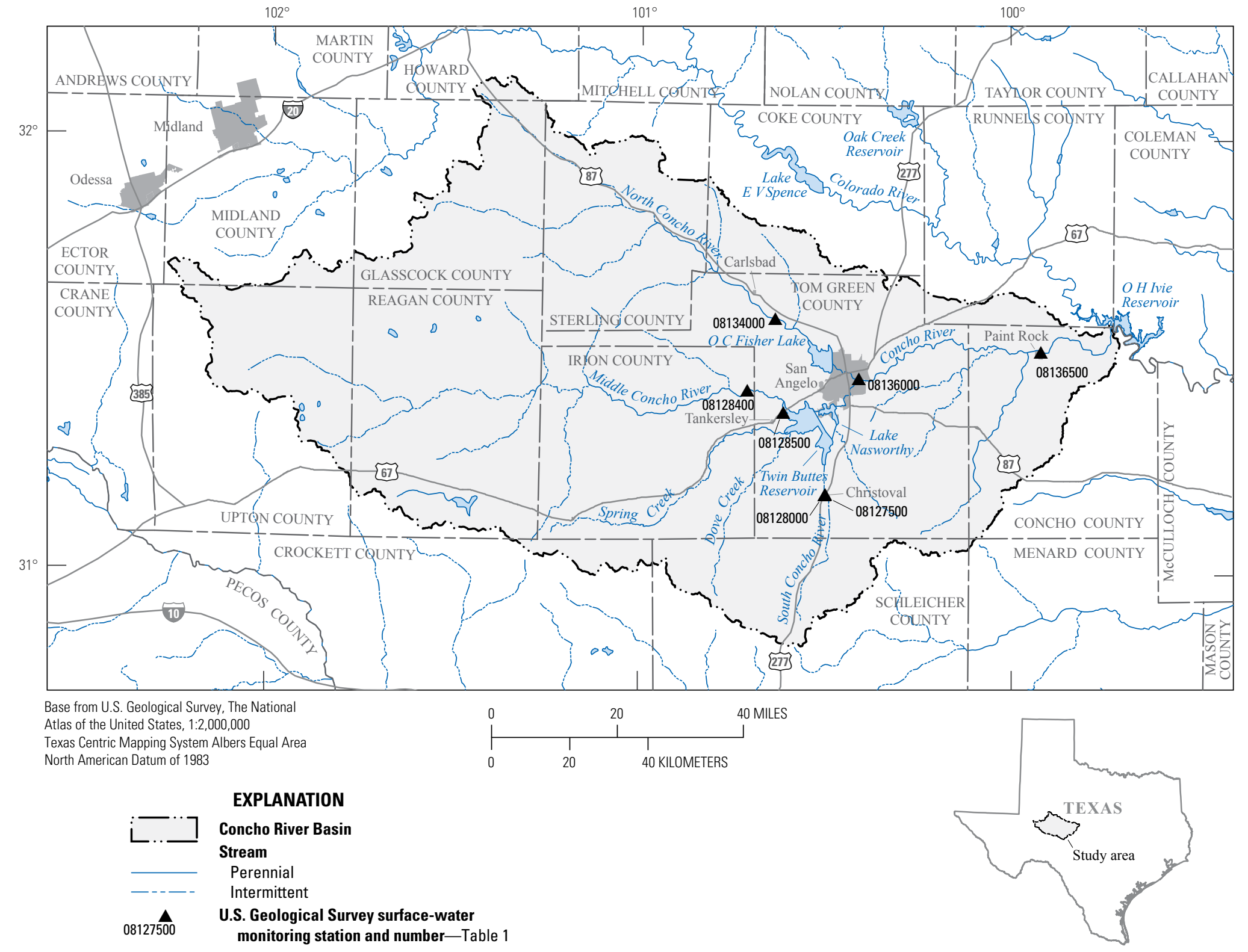

Figure 1. Selected U.S. Geological Survey surface-water monitoring stations in the Concho River Basin, Texas. 
evaluated trends during 1916-2009 in selected streamflow statistics for the Concho River Basin. Six USGS streamflowgaging stations were selected for analysis: 08128000 South Concho River at Christoval, Tex.; 08128400 Middle Concho River above Tankersley, Tex.; 08128500 Middle Concho River near Tankersley, Tex.; 08134000 North Concho River near Carlsbad, Tex.; 08136000 Concho River at San Angelo, Tex.; and 08136500 Concho River at Paint Rock, Tex. (fig. 1, table 1). In addition to the six streamflow-gaging stations listed in table 1, a USGS surface-water monitoring station used to monitor discharge in a canal is listed (station 08127500 South Concho Irrigation Company Canal at Christoval, Tex.). The use of the discharge data for this station and how it interacts with the analyses presented in this report is described in the section "Analysis of Trends in Selected Streamflow Statistics" pertaining to the South Concho River Basin.

The USGS has published statistical and historical summaries of streamflow data in Texas with great emphasis on visualization of streamflow data and statistics (Asquith and others, 2007a, b; Asquith and Heitmuller, 2008). These previous reports include similar and complementary statistical and graphical presentations of streamflow data for the six streamflow-gaging stations analyzed in this report. Lastly, the periods of annual instantaneous peak discharge for the six streamflow-gaging stations contribute to the regression equations by Asquith and Roussel (2009) that estimate peakstreamflow frequency in Texas.

\section{Purpose and Scope}

Monotonic trends in selected streamflow statistics in the Concho River Basin were evaluated for using a nonparametric test (Kendall's Tau) at selected USGS streamflow-gaging stations. Two types of USGS streamflow data comprise the foundational data for this report: (1) daily mean discharge (daily discharge) and (2) annual instantaneous peak discharge. Trends are reported for the following streamflow statistics: (1) annual mean daily discharge, (2) annual 1-day minimum discharge, (3) annual 7-day minimum discharge, (4) annual maximum daily discharge, and (5) annual instantaneous peak discharge. The scope of this report does not include an analysis of how possible changes in precipitation, land use, or groundwater withdrawals might have affected streamflow trends.

\section{Concho River Basin Description}

The South Concho, Middle Concho, and North Concho Rivers drain the upper part of the Concho River Basin. The Concho River and its tributaries generally flow from west to east with the exception of the South Concho River, which flows from south to north (fig. 1). Middle and South Concho Rivers join at Twin Buttes Reservoir (fig. 1) and continue downstream as the South Concho River. The Concho River is formed by the confluence of the South Concho and North Concho Rivers in San Angelo. From where it rises in San Angelo, the Concho River flows east about 60 miles (mi) to its confluence with the Colorado River, east of Paint Rock (fig. 1). Although the published drainage area of the Concho River Basin is about 6,765 square miles ( $\left.\mathrm{mi}^{2}\right)$ (U.S. Geological Survey, 2012), approximately $1,130 \mathrm{mi}^{2}$ of the basin are characterized by playas or other natural depressions that do not contribute runoff to the Concho River (Tovar and Maldonado, 1981). The contributing drainage area of the Concho River is about 5,634 $\mathrm{mi}^{2}$ (Tovar and Maldonado, 1981).

Table 1. Selected U.S. Geological Survey surface-water monitoring stations in the Concho River Basin, Texas, 1915-2009.

[USGS, U.S. Geological Survey; mi² $^{2}$ square miles; NA, not applicable]

\begin{tabular}{|c|c|c|c|c|c|c|}
\hline $\begin{array}{l}\text { USGS } \\
\text { station } \\
\text { number }\end{array}$ & USGS station name & $\begin{array}{c}\text { Gaging } \\
\text { station } \\
\text { type }\end{array}$ & $\begin{array}{c}\text { Total } \\
\text { drainage } \\
\text { area } \\
\left(\mathrm{mi}^{2}\right)\end{array}$ & $\begin{array}{c}\text { Contri- } \\
\text { buting } \\
\text { drainage } \\
\text { area } \\
\left(\mathrm{mi}^{2}\right)\end{array}$ & $\begin{array}{c}\text { Period of } \\
\text { continuous daily } \\
\text { mean discharge } \\
\text { record }\end{array}$ & $\begin{array}{c}\text { Water } \\
\text { years } \\
\text { statistically } \\
\text { evaluated }\end{array}$ \\
\hline 08127500 & South Concho Irrigation Company Canal at Christoval, Tex. & canal & NA & NA & Dec. 1939-Oct. 1983 & none \\
\hline 08128000 & South Concho River at Christoval, Tex. & stream & 413 & 354 & $\begin{array}{l}\text { Mar. 1930-Sept. } 1995 \text {; } \\
\text { May 2001-Sept. } 2009\end{array}$ & $\begin{array}{c}1931-95 \\
2002-9\end{array}$ \\
\hline 08128400 & Middle Concho River above Tankersley, Tex. & stream & 2,084 & 1,116 & $\begin{array}{l}\text { Apr. 1961-Sept. 1995; } \\
\text { Apr. 2001-Sept. } 2009\end{array}$ & $\begin{array}{c}1962-95 \\
2002-9\end{array}$ \\
\hline 08128500 & Middle Concho River near Tankersley, Tex. & stream & 2,653 & 1,685 & Mar. 1930-Mar. 1961 & $1931-60$ \\
\hline 08134000 & North Concho River near Carlsbad, Tex. & stream & 1,266 & 1,191 & Apr. 1924-Sept. 2009 & 1925-2009 \\
\hline 08136000 & Concho River at San Angelo, Tex. & stream & 5,542 & 4,411 & Oct. 1915-Sept. 2009 & 1916-2009 \\
\hline
\end{tabular}


The USGS has collected streamflow data in the Concho River Basin since October 1915. Since then and at various time intervals, up to 24 daily surface water stations (19 streamflow-gaging stations, 3 lake or reservoir stations, and 2 canal stations) have collected data in the basin through the present (2012). Two streamflow-gaging stations (the oldest in the basin) were installed in 1915 (Concho River at San Angelo and Concho River at Paint Rock), one was installed in 1924 (North Concho River near Carlsbad), and two were installed in 1930 (South Concho River at Christoval and Middle Concho River near Tankersley). The canal gage was installed in 1939 and discontinued in 1983. The South Concho River at Christoval, Middle Concho River near Tankersley, and Middle Concho River above Tankersley streamflowgaging stations are upstream from Twin Buttes Reservoir and Lake Nasworthy. The North Concho River near Carlsbad streamflow-gaging station is upstream from O.C. Fisher Lake. The Concho River at San Angelo and Concho River at Paint Rock streamflow-gaging stations are downstream from the three identified impoundments.

\section{Methods}

Trend analysis used in this study is based on application of the nonparametric Kendall's Tau statistical test to detect monotonic trends in streamflow with time (Helsel and Hirsch, 2002). A positive Tau indicates an upward monotonic streamflow trend; conversely, a negative Tau indicates a downward monotonic streamflow trend. The p-value of Kendall's Tau is a measure of the statistical significance of the trend. For this study, a p-value of less than 0.05 indicates a significant trend, whereas a p-value of 0.05 or greater indicates no significant trend. The trend analysis reported here is limited to direction and not magnitude of streamflow change.

Annual mean daily discharge is computed as the average of daily mean discharges during a water year (a water year is defined as the 12-month period from October 1 to September 30). The annual 1-day minimum discharge is the discharge on the day of lowest daily mean discharge in a given water year. Similarly, the annual 7-day minimum discharge is the lowest daily mean discharge during 7 consecutive days in a given water year. The annual maximum daily discharge is the discharge on the day of highest annual daily mean discharge in a given water year. The annual instantaneous peak discharge is the discharge associated with the highest instantaneous streamflow computed in a given water year; this statistic is fundamentally different from the other four streamflow statistics because there is no time averaging involved. The date of the annual instantaneous peak discharge is not constrained to occur on the same day as the annual maximum daily discharge. To conduct the trend analysis, the software package Statistica (StatSoft, 2009) was used to perform the Kendall's Tau test. For each of the six streamflow-gaging stations, Kendall's Tau statistics were computed for the five streamflow statistics; the precise period of records evaluated by streamflow-gaging station are listed in table 1 .

There is an important limitation of the Kendall's Tau statistical test when applied to streamflow time series data that might contain a substantial number of years with no flow for annual 1-day (or 7-day) minimum discharge. The Tau and the attendant p-value become highly unreliable and direct interpretation of their numerical meaning can become tenuous because of ties. In many nonparametric statistical tests, considerable accommodation of ties in the data set can be made but are only approximations. For this study, the trend analysis of annual 1-day and 7-day minimum daily discharge for streamflow-gaging stations 08128400 Middle Concho River above Tankersley and 08128500 Middle Concho River near Tankersley yield Tau and p-values that are difficult to interpret and hence specially noted when the trends analysis is presented in tabular form.

\section{Analysis of Trends in Selected Streamflow Statistics}

\section{South Concho River Basin}

The headwaters of the South Concho River are in north Schleicher County (fig. 1) approximately $40 \mathrm{mi}$ south of San Angelo. The river flows north into Twin Buttes Reservoir. The South Concho Irrigation Company Canal diverts water upstream from the South Concho River at Christoval streamflow-gaging station and returns water to the river downstream from the streamflow-gaging station. The canal gaging station was operated from December 1939 through October 1983 (table 1) and the South Concho River at Christoval streamflow-gaging station was operated from March 1930 through September 1995 and reactivated from May 2001 to the present (2012). The return discharge from the canal into the river is less than the discharge diverted into the canal upstream because of withdrawals for irrigation and evaporation losses (Sauer, 1972). The sum of the discharge in the canal and the discharge at the nearby streamflow-gaging station can be used as an estimate for the total South Concho River discharge during the period of mutual operation. The three time series of annual mean discharges shown in figure 2 indicate that the estimated combined annual mean streamflow does not materially vary or diverge from patterns seen in the South Concho River at Christoval annual mean streamflow. Hence, for this report, the five statistics of South Concho River at Christoval streamflow were evaluated for monotonic trends, and a benefit of this decision is that a longer period of record (blue line in fig. 2) is available for analysis without inclusion of the streamflow in the canal.

For the South Concho River at Christoval streamflowgaging station, statistically significant downward trends 


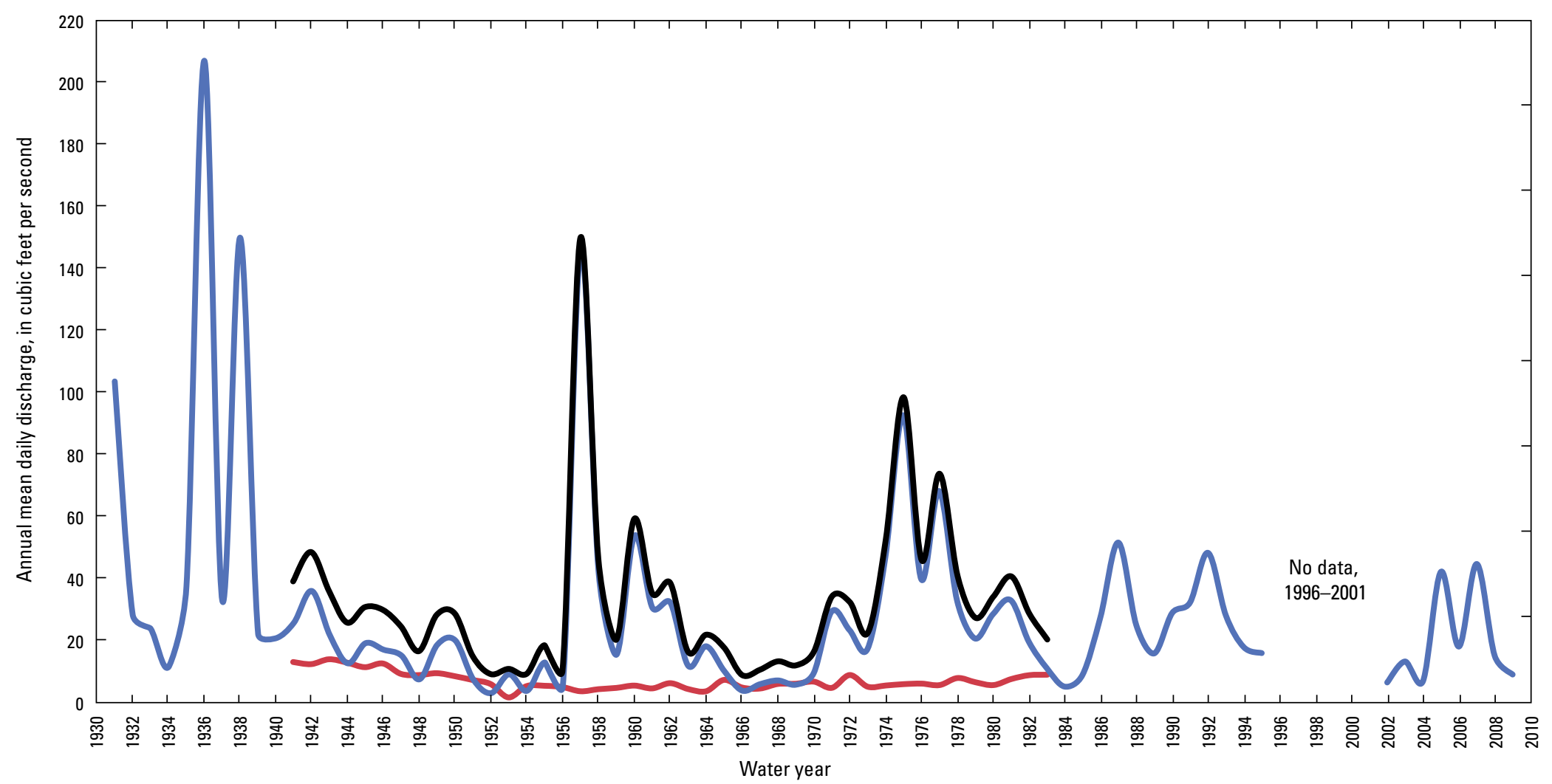

EXPLANATION

08127500 South Concho Irrigation Canal at Christoval, Texas

08128000 South Concho River at Christoval, Texas

Estimated combined annual mean daily discharge

Figure 2. Annual mean daily discharge for U.S. Geological Survey surface-water monitoring stations 08128000 South Concho River near Christoval, Texas and 08127500 South Concho Irrigation Canal at Christoval, Tex., along with the estimated combined annual mean daily discharge. 
in streamflow for the combined period 1931-95 and 2002-9 were detected for annual maximum daily discharge and annual instantaneous peak discharge (table 2). No statistically significant trends were detected for the other three streamflow statistics.

\section{Middle Concho River Basin}

The headwaters of the Middle Concho River are approximately $90 \mathrm{mi}$ west of San Angelo. The river flows east into Twin Buttes Reservoir (fig. 1). The two Middle Concho River streamflow-gaging stations were not operated concurrently (table 1), visually indicated by the plotted annual mean daily discharges for the streamflow-gaging stations shown in figure 3. The upstream streamflow-gaging station 08128400 Middle Concho River above Tankersley, Tex., (drainage area $1,116 \mathrm{mi}^{2}$ ) was a replacement for streamflow-gaging station 08128500 Middle Concho River near Tankersley, Tex. (drainage area 1,685 $\mathrm{mi}^{2}$ ). The Middle Concho River near Tankersley streamflow-gaging station was discontinued on March 31, 1961, in order to accommodate the construction of Twin Buttes Reservoir. The Middle Concho River above Tankersley streamflow-gaging station began operating April 1, 1961. This streamflow-gaging station transition occurred at the beginning of a multi-year period of unusually low streamflow. For example in 1962, the annual mean discharge was no flow (fig. 3).

For the Middle Concho River above Tankersley streamflow-gaging station, statistically significant downward trends in streamflow for the combined period 1962-95 and 2002-9 were detected for annual maximum daily discharge and annual instantaneous peak discharge at (table 3a). No statistically significant trends were detected for the other three streamflow statistics. For the Middle Concho River near Tankersley streamflow-gaging station, no statistically significant trends were detected for all five streamflow statistics for the period 1931-60 (table 3b).

\section{North Concho River Basin}

The headwaters of the North Concho River are approximately $70 \mathrm{mi}$ northwest of San Angelo. The North Concho River flows from northwest to southeast into O.C. Fisher Lake (fig. 1). The North Concho River near Carlsbad streamflow-gaging station is a particularly important sentinel for streamflow conditions for much of the greater Concho River Basin. Specifically, the streamflow at this streamflowgaging station is considered natural to the extent that the upstream watershed has effectively no diversions or regulation during the 85 years of record (April 1924-September 2009). The annual mean discharge for the North Concho River near Carlsbad is shown in figure 4.

For the North Concho River near Carlsbad streamflowgaging station, statistically significant downward trends for the period 1925-2009 were detected for annual mean daily discharge (fig. 4), annual 7-day minimum discharge, annual maximum daily discharge, and annual instantaneous peak discharge (table 4).

\section{Lower Concho River Basin}

Three impoundments regulate streamflow in the Concho River Basin: Lake Nasworthy (since 1930), O.C. Fisher Lake (since 1952), and Twin Buttes Reservoir (since 1963) (Dowell, 1964; U.S. Geological Survey, 2012). These impoundments are upstream from the Concho River mainstem that originates just downstream from the reservoirs at San Angelo. These impoundments then substantially regulate low to high streamflows observed at the Concho River at San Angelo and Concho River at Paint Rock streamflow-gaging stations. Both O.C. Fisher Lake and Twin Buttes Reservoir did not initially yield the public water supply anticipated from the reservoir designs that were based on the existing streamflow records in Concho River Basin (Sauer, 1972). Since impoundment began in 1952, the only time the conservation pool level in

Table 2. Results of Kendall's Tau statistical test for detection of monotonic trends in select streamflow statistics for U.S. Geological Survey streamflow-gaging station 08128000 South Concho River at Christoval, Texas.

[p-value, probability value; $<$, less than]

\begin{tabular}{lcccl}
\hline \multicolumn{1}{c}{$\begin{array}{c}\text { Streamflow } \\
\text { statistic }\end{array}$} & $\begin{array}{c}\text { Interval } \\
\text { analyzed }\end{array}$ & $\begin{array}{c}\text { Kendall's } \\
\text { Tau }\end{array}$ & p-value & Trend \\
\hline Annual mean daily discharge & $1931-95,2002-9$ & -0.07 & 0.40 & not significant \\
Annual 1-day minimum discharge & $1931-95,2002-9$ & 0.14 & 0.08 & not significant \\
Annual 7-day minimum discharge & $1931-95,2002-9$ & 0.12 & 0.13 & not significant \\
Annual maximum daily discharge & $1931-95,2002-9$ & -0.19 & $<0.05$ & downward \\
Annual instantaneous peak discharge & $1931-95,2002-9$ & -0.22 & $<0.05$ & downward \\
\hline
\end{tabular}




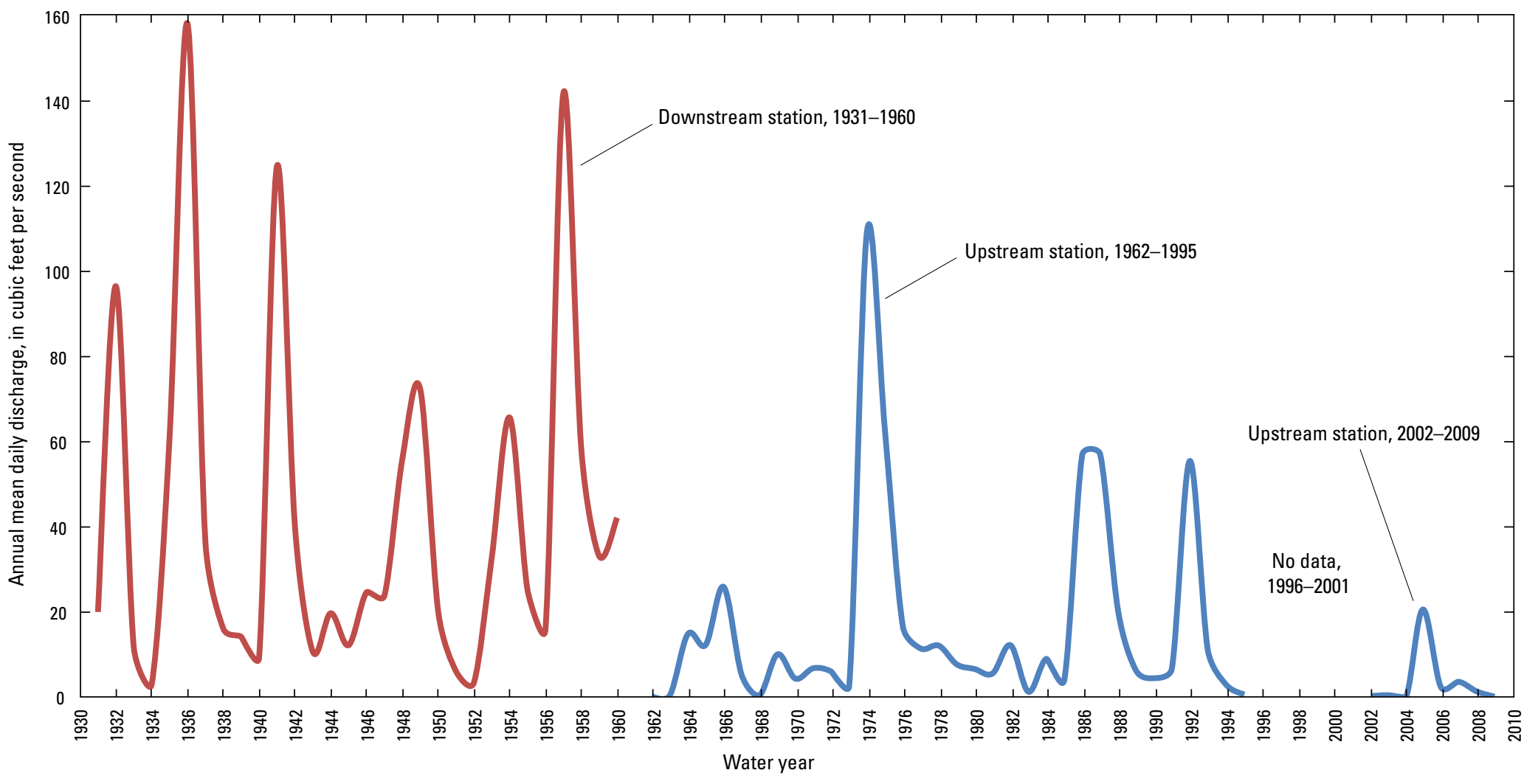

\section{EXPLANATION}

\section{Middle Concho River above Tankersley, Texas}

08128500 Middle Concho River near Tankersley, Texas

Figure 3. Annual mean daily discharge for U.S. Geological Survey streamflow-gaging stations 08128400 Middle Concho River above Tankersley, Texas, and 08128500 Middle Concho River near Tankersley, Tex. 
Table 3. Results of Kendall's Tau statistical test for detection of monotonic trends in select streamflow statistics for $A$, U.S. Geological Survey streamflow-gaging station 08128400 Middle Concho River above Tankersley, Texas, and B, U.S. Geological Survey streamflowgaging station 08128500 Middle Concho River near Tankersley, Tex.

[USGS, U.S. Geological Survey; p-value, probability value; <, less than]

A, USGS streamflow-gaging station 08128400 Middle Concho River above Tankersley, Tex.

\begin{tabular}{lcccc}
\hline \multicolumn{1}{c}{$\begin{array}{c}\text { Streamflow } \\
\text { statistic }\end{array}$} & $\begin{array}{c}\text { Interval } \\
\text { analyzed }\end{array}$ & $\begin{array}{c}\text { Kendall's } \\
\text { Tau }\end{array}$ & p-value & Trend \\
\hline Annual mean daily discharge & $1962-95,2002-9$ & -0.17 & 0.10 & not significant \\
Annual 1-day minimum discharge & $1962-95,2002-9$ & 10.75 & 0.2 & not significant \\
Annual 7-day minimum discharge & $1962-95,2002-9$ & 10.67 & 0.1 & not significant \\
Annual maximum daily discharge & $1962-95,2002-9$ & -0.25 & $<0.05$ & downward \\
Annual instantaneous peak discharge & $1962-95,2002-9$ & -0.24 & $<0.05$ & downward \\
\hline
\end{tabular}

$B$, USGS streamflow-gaging station 08128500 Middle Concho River near Tankersley, Tex.

$\begin{array}{lllll}\text { Annual mean daily discharge } & 1931-60 & 0.10 & 0.44 & \text { not significant } \\ \text { Annual 1-day minimum discharge } & 1931-60 & 0.04 & 0.5 & \text { not significant } \\ \text { Annual 7-day minimum discharge } & 1931-60 & 0.04 & 0.5 & \text { not significant } \\ \text { Annual maximum daily discharge } & 1931-60 & 0.10 & 0.45 & \text { not significant } \\ \text { Annual instantaneous peak discharge } & 1931-60 & 0.07 & 0.57 & \text { not significant }\end{array}$

${ }^{1}$ The numerical values for Kendall's Tau and attendant p-value are considered approximate and difficult to interpret because of substantial number of zero flow values for the annual 1-day and 7-day minimum discharges.

O.C. Fisher Lake was attained occurred in 1957 (U.S. Army Corps of Engineers, 2005). Water levels in Twin Buttes Reservoir did not reach the conservation pool elevation until 1974 (approximately 11 years after completion) (Zuniga, 1999). Controlled releases, or lack thereof, from the impoundments have significantly reduced flood peaks at the Concho River streamflow-gaging stations. The two Concho River streamflow-gaging stations were analyzed for their period of record (1916-2009) and for the period in which of all three impoundments provided regulation (1964-2009).

\section{Concho River at San Angelo}

The Concho River at San Angelo streamflow-gaging station is $0.4 \mathrm{mi}$ downstream from the confluence of the North and South Concho Rivers in the eastern part of the city of San Angelo. The streamflow-gaging station is approximately 6 mi downstream from Lake Nasworthy, approximately $5 \mathrm{mi}$ downstream from O.C. Fisher Lake, and approximately $60 \mathrm{mi}$ upstream from the mouth (fig. 1). The annual mean discharge for the Concho River at San Angelo is shown in figure 5.

For the Concho River at San Angelo streamflow-gaging station, statistically significant downward trends for the period 1916-2009 were detected for all five streamflow statistics (table 5). No statistically significant trends for the period 1964-2009 were detected except that annual maximum daily discharge has an upward trend (table 5). The downward trends detected for the period 1916-2009 are not unexpected because of three reservoirs impounding and controlling streamflow.

\section{Concho River at Paint Rock, Texas}

The Concho River at Paint Rock streamflow-gaging station is $20 \mathrm{mi}$ upstream from the mouth of Concho River (fig. 1) and is approximately $42 \mathrm{mi}$ downstream from San Angelo. The streamflow-gaging station represents the terminal streamflow data collection point in the Concho River Basin. The annual mean daily discharge for the Concho River at Paint Rock is shown in figure 6 .

For the Concho River at Paint Rock streamflow-gaging station, statistically significant downward trends for the period 1916-2009 were detected for all five streamflow statistics (table 6). No statistically significant trends were detected for the period 1964-2009 for all five statistics (table 6). The downward trends detected for the period 1916-2009 are not unexpected because of three reservoirs impounding and controlling streamflow. 


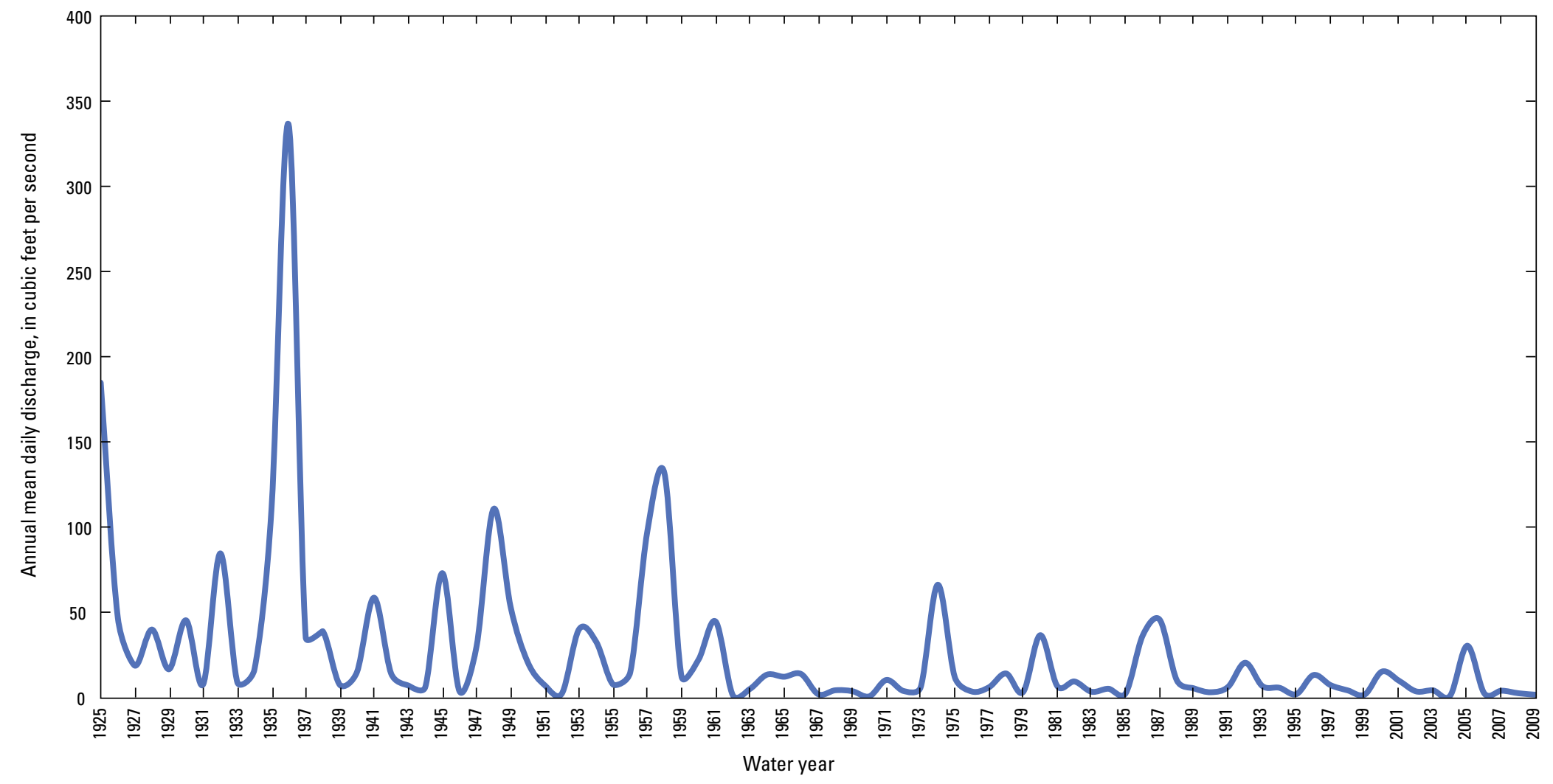

Figure 4. Annual mean daily discharge for U.S. Geological Survey streamflow-gaging station 08134000 North Concho River near Carlsbad, Texas. 
10 Analysis of Trends in Selected Streamflow Statistics for the Concho River Basin, Texas, 1916-2009

Table 4. Results of Kendall's Tau statistical test for detection of monotonic trends in select streamflow statistics for U.S. Geological Survey streamflow-gaging station 08134000 North Concho River near Carlsbad, Texas.

[p-value, probability value; $<$, less than]

\begin{tabular}{lcccc}
\hline \multicolumn{1}{c}{$\begin{array}{c}\text { Streamflow } \\
\text { statistic }\end{array}$} & $\begin{array}{c}\text { Interval } \\
\text { analyzed }\end{array}$ & $\begin{array}{c}\text { Kendall's } \\
\text { Tau }\end{array}$ & p-value & Trend \\
\hline Annual mean daily discharge & $1925-2009$ & -0.39 & $<0.05$ & downward \\
Annual 1-day minimum discharge & $1925-2009$ & 0.14 & 0.06 & $<0.05$ \\
Annual 7-day minimum discharge & $1925-2009$ & -0.17 & $<0.05$ & downward significant \\
Annual maximum daily discharge & $1925-2009$ & -0.35 & $<0.05$ & downward \\
Annual instantaneous peak discharge & $1925-2009$ & -0.36 & downward \\
\hline
\end{tabular}




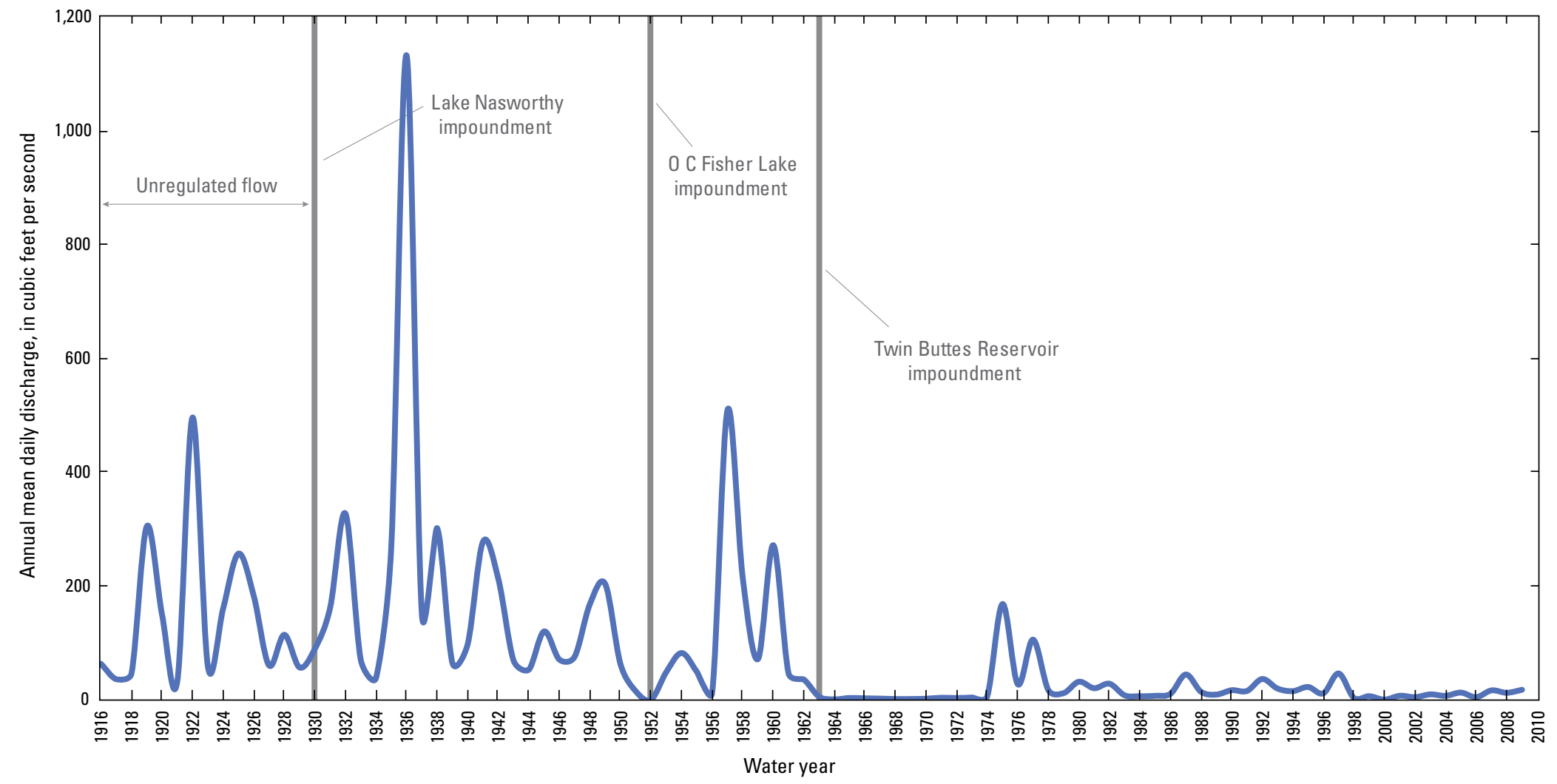

Figure 5. Annual mean daily discharge for U.S. Geological Survey streamflow-gaging station 08136000 Concho River at San Angelo, Texas. 


\section{Analysis of Trends in Selected Streamflow Statistics for the Concho River Basin, Texas, 1916-2009}

Table 5. Results of Kendall's Tau statistical test for detection of monotonic trends in select streamflow statistics for U.S. Geological Survey streamflow-gaging station 08136000 Concho River at San Angelo, Texas.

[p-value, probability value; $<$, less than]

\begin{tabular}{lcccl}
\hline \multicolumn{1}{c}{$\begin{array}{c}\text { Streamflow } \\
\text { statistic }\end{array}$} & $\begin{array}{c}\text { Interval } \\
\text { analyzed }\end{array}$ & $\begin{array}{c}\text { Kendall's } \\
\text { Tau }\end{array}$ & p-value & Trend \\
\hline Annual mean daily discharge & $1916-2009$ & -0.41 & $<0.05$ & downward \\
Annual 1-day minimum discharge & $1916-2009$ & -0.35 & $<0.05$ & downward \\
Annual 7-day minimum discharge & $1916-2009$ & -0.25 & $<0.05$ & downward \\
Annual maximum daily discharge & $1916-2009$ & -0.37 & $<0.05$ & downward \\
Annual instantaneous peak discharge & $1916-2009$ & -0.42 & $<0.05$ & downward \\
Annual mean daily discharge & $1964-2009$ & 0.20 & 0.05 & not significant \\
Annual 1-day minimum discharge & $1964-2009$ & -0.13 & 0.20 & not significant \\
Annual 7-day minimum discharge & $1964-2009$ & -0.10 & 0.34 & not significant \\
Annual maximum daily discharge & $1964-2009$ & 0.24 & $<0.05$ & upward \\
Annual instantaneous peak discharge & $1964-2009$ & 0.06 & 0.54 & not significant \\
\hline
\end{tabular}




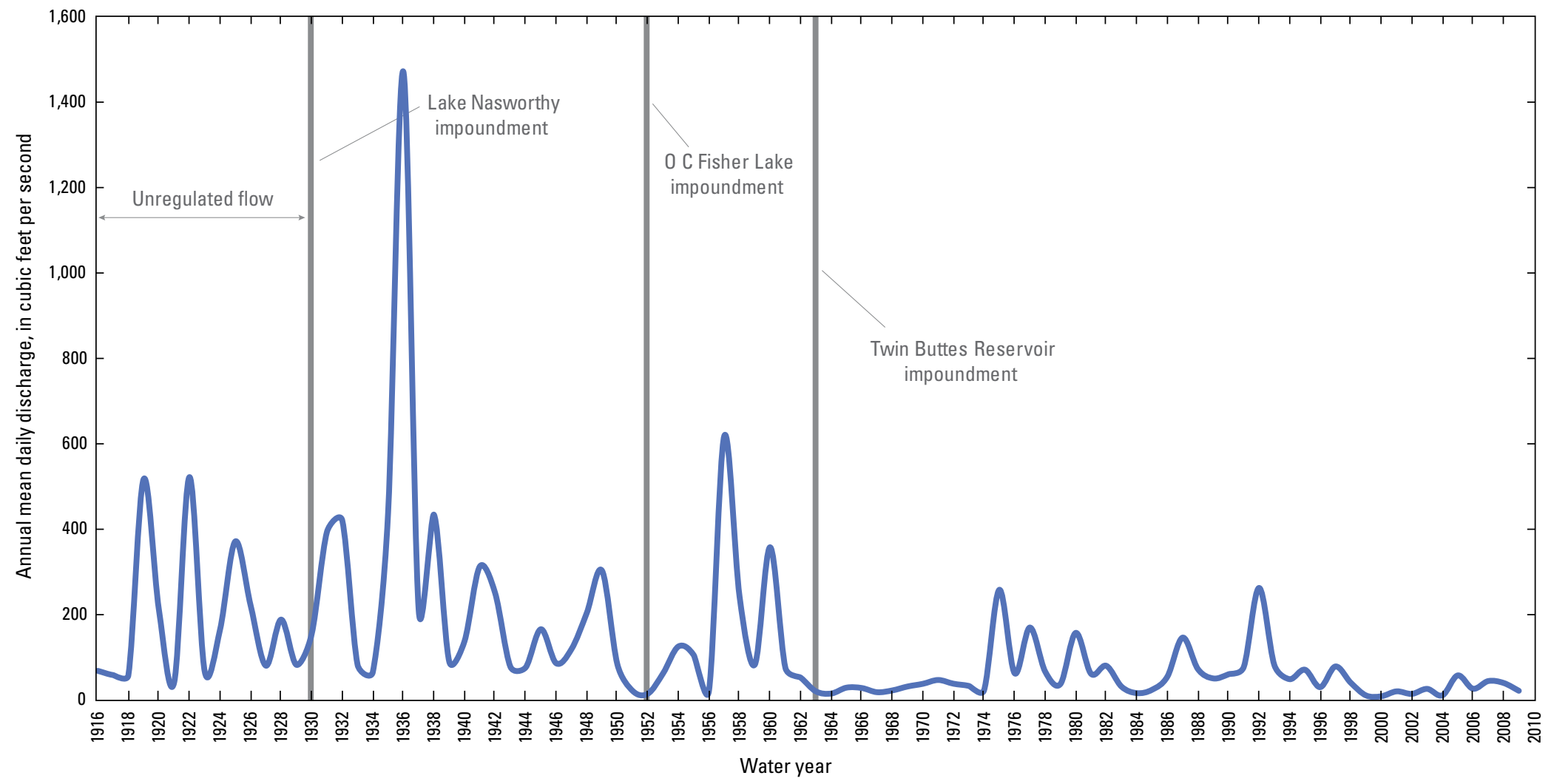

Figure 6. Annual mean daily discharge for U.S. Geological Survey streamflow-gaging station 08136500 Concho River at Paint Rock, Texas. 
Table 6. Results of Kendall's Tau statistical test for detection of monotonic trends in select streamflow statistics for U.S. Geological Survey streamflow-gaging station 08136500 Concho River at Paint Rock, Texas.

[p-value, probability value; $<$, less than]

\begin{tabular}{lccll}
\hline \multicolumn{1}{c}{$\begin{array}{c}\text { Streamflow } \\
\text { statistic }\end{array}$} & $\begin{array}{c}\text { Interval } \\
\text { analyzed }\end{array}$ & $\begin{array}{c}\text { Kendall's } \\
\text { Tau }\end{array}$ & p-value & Trend \\
\hline Annual mean daily discharge & $1916-2009$ & -0.37 & $<0.05$ & downward \\
Annual 1-day minimum discharge & $1916-2009$ & 0.14 & $<0.05$ & downward \\
Annual 7-day minimum discharge & $1916-2009$ & 0.14 & $<0.05$ & downward \\
Annual maximum daily discharge & $1916-2009$ & -0.41 & $<0.05$ & downward \\
Annual instantaneous peak discharge & $1916-2009$ & -0.43 & $<0.05$ & downward \\
Annual mean daily discharge & $1964-2009$ & -0.03 & 0.77 & not significant \\
Annual 1-day minimum discharge & $1964-2009$ & -0.12 & 0.22 & not significant \\
Annual 7-day minimum discharge & $1964-2009$ & -0.07 & 0.45 & not significant \\
Annual maximum daily discharge & $1964-2009$ & -0.03 & 0.75 & not significant \\
Annual instantaneous peak discharge & $1964-2009$ & -0.06 & 0.58 & not significant \\
\hline
\end{tabular}

\section{Summary}

The Concho River Basin is part of the upper Colorado River Basin in west-central Texas. Streamflow (surface water) supplies some irrigation water and the majority of the public water supply. Public water supply historically has been provided by streamflow stored in O.H. Ivie and Twin Buttes Reservoirs, Lakes Nasworthy and E.V. Spence, and O.C. Fisher Lake. Because the Concho River Basin provides water stored for public water supply for most residents in the study area, trends in streamflow in the Concho River Basin are of interest to water managers in this part of west Texas. Accordingly, the U.S. Geological Survey (USGS), in cooperation with the Texas Water Development Board, evaluated trends during 1916-2009 in selected streamflow statistics for the Concho River Basin. Monotonic trends in streamflow were evaluated using a nonparametric test (Kendall's Tau) to evaluate whether statistically significant changes in the selected streamflow statistics have occurred over time within the Concho River Basin at six USGS streamflow-gaging stations: 08128000 South Concho River at Christoval, Tex.; 08128400 Middle Concho River above Tankersley, Tex.; 08128500 Middle Concho River near Tankersley, Tex.; 08134000 North Concho River near Carlsbad, Tex.; 08136000 Concho River at San Angelo, Tex.; and 08136500 Concho River at Paint Rock, Tex. Two types of USGS streamflow data comprise the foundational data for this report: (1) daily mean discharge (daily discharge) and (2) annual instantaneous peak discharge. Trends are reported for the following streamflow statistics: (1) annual mean daily discharge, (2) annual 1-day minimum discharge, (3) annual 7-day minimum discharge, (4) annual maximum daily discharge, and (5) annual instantaneous peak discharge.

The USGS has collected streamflow data in the Concho River Basin since October 1915. Since then and at various time intervals, as many as 24 daily surface-water monitoring stations (19 streamflow-gaging stations, 3 lake or reservoir stations, and 2 canal stations) have been used to collect data in the basin through the present (2012). Trend analyses used in this study are based on application of the nonparametric Kendall's Tau statistical test to detect monotonic trends in streamflow with time. A positive Tau indicates an upward monotonic streamflow trend; conversely, a negative Tau indicates a downward monotonic streamflow trend. The p-value of Kendall's Tau is a measure of the statistical significance of the trend. For this study, a p-value of less than 0.05 indicates a significant trend, whereas a p-value of 0.05 or greater indicates no significant trend.

For USGS streamflow-gaging station 08128000 South Concho River at Christoval, Tex., statistically significant downward trends in streamflow for the combined period 1931-95 and 2002-9 were detected for annual maximum daily discharge and annual instantaneous peak discharge. For USGS streamflow-gaging station 08128400 Middle Concho River above Tankersley, Tex., statistically significant downward trends in streamflow for the combined period 1962-95 and 2002-9 were detected for annual maximum daily discharge and annual instantaneous peak discharge. For USGS streamflow-gaging station 08128500 Middle Concho River near Tankersley, Tex., no statistically significant trends were detected for all five streamflow statistics for the period 
1931-60. For USGS streamflow-gaging station 08134000 North Concho River near Carlsbad, Tex., statistically significant downward trends for the period 1925-2009 were detected for annual mean daily discharge, annual 7-day minimum discharge, annual maximum daily discharge, and annual instantaneous peak discharge. For USGS streamflowgaging station 08136000 Concho River at San Angelo, Tex., statistically significant downward trends for the period 1916-2009 were detected for all five streamflow statistics. No statistically significant trends for the period 1964-2009 were detected except that annual maximum daily discharge has an upward trend. For USGS streamflow-gaging station 08136500 Concho River at Paint Rock, Tex., statistically significant downward trends for the period 1916-2009 were detected for all five streamflow statistics. No statistically significant trends for the period 1964-2009 were detected. The downward trends detected for the period 1916-2009 are not unexpected because of three reservoirs impounding and controlling streamflow.

\section{References Cited}

Asquith, W.H., Vrabel, Joseph, and Roussel, M.C., 2007a, Summary of percentages of zero daily mean streamflow for 712 U.S. Geological Survey streamflow-gaging stations in Texas through 2003: U.S. Geological Survey Data Series 247, 721 p. (Also available at http://pubs.usgs.gov/ ds $/ 2007 / 247 /$.)

Asquith, W.H., Vrabel, Joseph, and Roussel, M.C., 2007b, Summary of annual mean, maximum, minimum, and L-scale statistics of daily mean streamflow for 712 U.S. Geological Survey streamflow-gaging stations in Texas through 2003: U.S. Geological Survey Data Series 248, 721 p. (Also available at http://pubs.usgs.gov/ds/2007/248/.)

Asquith, W.H., and Heitmuller, F.T., 2008, Summary of annual mean and annual harmonic mean statistics of daily mean streamflow for 620 U.S. Geological Survey streamflowgaging stations in Texas through water year 2007: U.S. Geological Survey Data Series 372, 1,259 p. (Also available at http://pubs.usgs.gov/ds/372/.)

Asquith, W.H., and Roussel, M.C., 2009, Regression equations for estimation of annual peak-streamflow frequency for undeveloped watersheds in Texas using an L-momentbased, PRESS-minimized, residual-adjusted approach: U.S. Geological Survey Scientific Investigations Report 2009-5087, 48 p. (Also available at http://pubs.usgs.gov/ $\operatorname{sir} / 2009 / 5087$.
Dowell, C.L., 1964, Dams and reservoirs in TexasHistorical and descriptive information: Texas Water commission Bulletin 6408, accessed June 6, 2012, at http://www.twdb.texas.gov/publications/reports/bulletins/ doc/B6408.pdf.

Helsel, D.R., and Hirsch, R.M., 2002, Statistical methods in water resources: U.S. Geological Survey Techniques of Water-Resources Investigations book 4, chap. A3 (Also available at http://pubs.usgs.gov/twri/twri4a3.)

Sauer, S.P., 1972, Factors contributing to unusually low runoff during the period 1962-1968 in the Concho River basin, Texas: U.S. Geological Survey Water Supply Paper 1999-L, $48 \mathrm{p}$.

StatSoft, 2009, STATISTICA 10, version 10.0.1011.4: Tulsa, Okla., StatSoft Inc.

Region F Water Planning Group, 2009, Irrigation SurveyGlasscock, Midland, Reagan, Pecos, Reeves and Tom Green Counties: prepared by Freese and Nichols, Inc., and LBG-Guyton Associates, Inc., accessed August 21, 2012, at http://www.regionfwater.org/files/regionf/Final_Irrigation Report_April_2009.pdf.

Tovar, F.H., and Maldonado, B.N., 1981, Drainage areas of Texas streams, Colorado River basin: Texas Department of Water Resources, Report LP-145.

U.S. Army Corps of Engineers, 2005, Detailed project report and integrated environmental assessment for O.C. Fisher Lake Ecosystem Project, San Angelo, Texas: Prepared for the City of San Angelo, US Army Corps of Engineers, Fort Worth District. (Also available at http://media.swf.usace.army.mil/pubdata/notices/EA/ OCFisher/OCFisherdraftDPR19JUL PUBLIC REVIEW. pdf).

U.S. Geological Survey, 2012, Water-resources data for the United States, water year 2009: U.S. Geological Survey Water Data Report WDR-US-2011, accessed June 6, 2012, at http://wdr.water.usgs.gov/.

U.S. Census Bureau, 2012, San Angelo Texas quick facts: accessed April 4, 2012, at http://quickfacts.census.gov/qfd/ states/48/4864472.html.

Zuniga, J.E., 1999, San Angelo Project: Bureau of Reclamation, U.S. Department of Interior (Also available at http://www.usbr.gov/projects//ImageServer?imgName= Doc_1305641134133.pdf.) 
Publishing support provided by

Lafayette and Menlo Publishing Service Centers

Information regarding water resources in Texas is available at http://tx.usgs.gov/ 


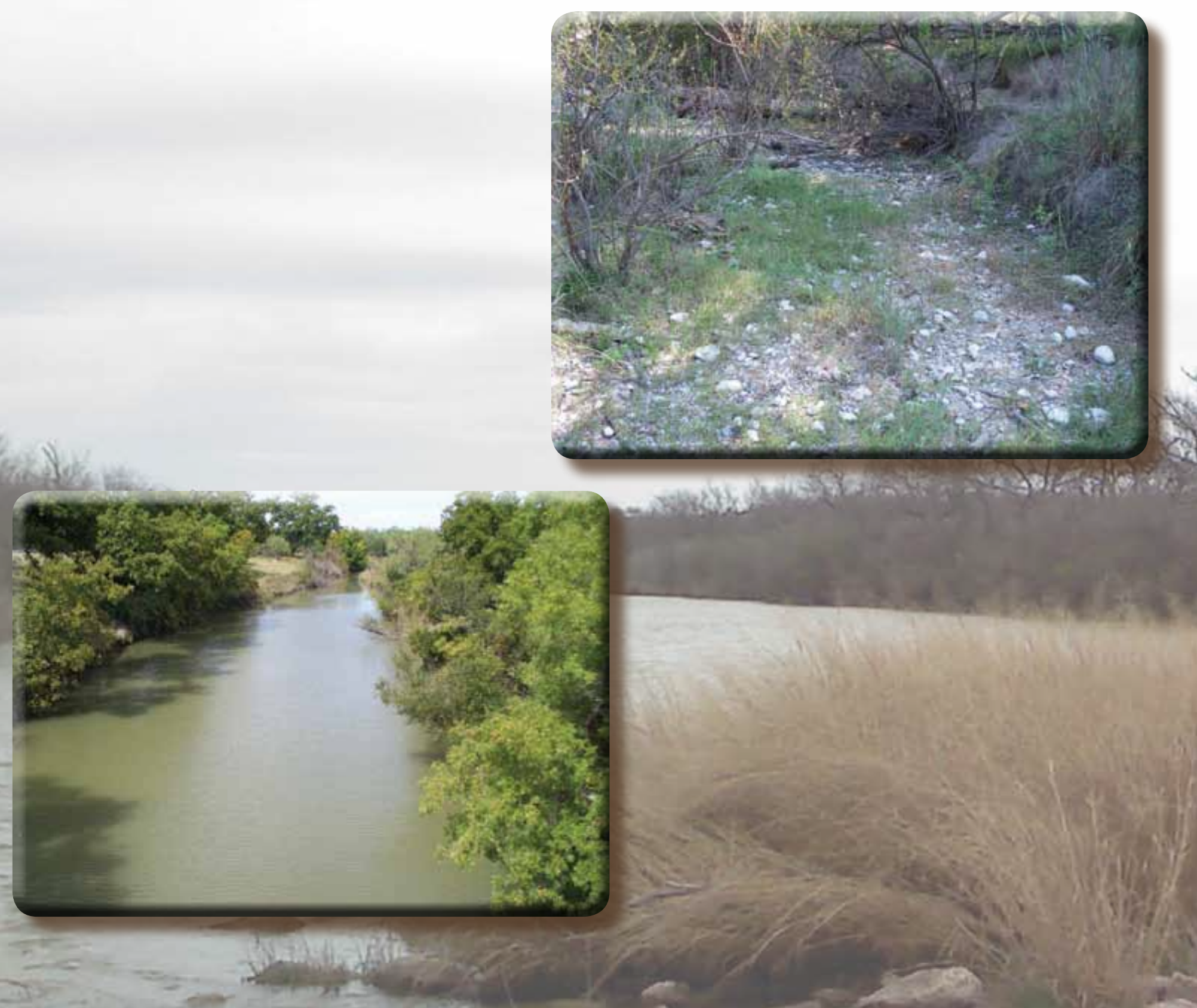